\title{
Thus far but no further: predatory mites do not migrate effectively into strawberry plantations
}

\author{
D. Sikorska ${ }^{1,2}$ (I) . J. Garnis ${ }^{3}$ - Z. T. Dąbrowski ${ }^{3} \cdot$ P. Sikorski ${ }^{4}$ D. Gozdowski ${ }^{5}$. \\ R. J. Hopkins ${ }^{6}$
}

Received: 24 January 2018 / Accepted: 5 March 2019 / Published online: 27 March 2019

(c) The Author(s) 2019

\begin{abstract}
Enhancing the performance of predatory mites is often regarded as the best biological control approach towards the spider mite Tetranychus urticae, the main pest of strawberry plantations. Optimizing the colonization of plantations by predators from adjacent areas such as field margins is seen as an important component of conservation biocontrol. We have investigated the factors contributing to enhancing the numbers of predatory mites (Acari: Phytoseidae), such as management of the field margins, vegetation composition and the effect of the presence of woody species. We also tested the penetration of the phytoseiids from the field margins into the crop. In a study carried out in 14 open-field extensively managed strawberry plantations in Poland we found phytoseiids to be abundant in field margins; 14 taxa were discovered. However, only two species Amblyseius andersoni and Euseius finlandicus dispersed a modest distance into the crop. We found that the diversity and densities of the predatory mites were enhanced somewhat by the management type of the field margins; especially the spontaneous vegetation favoured the presence of phytoseiids. However, despite the predatory mites being rather retained in the field margins also significant reduction in numbers of their prey T. urticae was recorded over the course of the year. The low penetration of predatory mites into the main part of the field, indicates that conservation biological control measures in the field margin might not be sufficient on their own to enhance the impact of predatory mites within the main part of the fields.
\end{abstract}

Keywords Field margin $\cdot$ Biological control $\cdot$ Phytoseidae $\cdot$ IPM $\cdot$ Diversity

\section{Introduction}

Integrated pest management (IPM) is increasingly regarded as a workable contribution to meet the challenges of minimising the environmental impacts of chemical pest control, whilst maintaining crop production with a declining list of pesticide alternatives (Wissuwa et al. 2012; McMurtry et al. 2014). For the management of insects and mites, a key component of IPM schemes is conservation biological control, which seeks to combat pest

D. Sikorska

daria_sikorska@sggw.pl

Extended author information available on the last page of the article 
problems by modification of the environment to protect and enhance specific natural enemies, thus reducing the impact of pests (Bale et al. 2008; Barzman et al. 2015). The natural vegetation of field margins shows a relatively high diversity of beneficial insects and mites (Denys and Tscharntke 2002). Diverse field margins supply a diversity of pollen species, which are an important alternative food source for polyphagous predatory mite species (Acari: Phytoseiidae) (Duso et al. 2004), and these mites can migrate the short distance between field margins and crops (Boller et al. 1988; Tixier et al. 2000, 2006; Shimoda and Takabayashi 2001; Cruz et al. 2013). However, the factors determining the impact of natural systems on biological control and the spatial relationships between predatory mites and the crop are both still poorly understood.

Herbivorous mites present a major threat to strawberry crops, particularly spider mites (Tetranychidae), whose high densities can lead to a reduction in both the quantity and the quality of harvested fruit. In strawberry fields, Tetranychus urticae Koch is the most common invertebrate pest, significantly reducing yield (Sances et al. 1982). Although Tetranychidae species tend to develop resistance to acaricides, it is still controlled mostly with pesticides (Tirello et al. 2012). Consequently, IPM is reasserting the importance of sustainable methods of control, including developing genetic resistance (Figueiredo et al. 2012) and enhancing favourable conditions for natural enemies (Hajek 2004; Ramsden et al. 2015). Populations of T. urticae can be effectively limited using predatory mites from the Phytoseiidae family, which occur commonly on the spontaneous vegetation of field margins (Niemczyk 2000; McMurtry et al. 2013). Field margin vegetation has been shown to provide alternative prey or food resources and refuges for overwintering of beneficial arthropods, including mites (Boller et al. 1988; Marshall and Moonen 2002; Romero and Benson 2005; Tixier et al. 2000).

The colonization of strawberry plantations by naturally occurring predatory mites is strongly dependent on the surrounding vegetation (Cruz et al. 2013; Lagerlöf and Wallin 1993). However, rapid and effective colonization is required to keep the number of herbivorous mites below economic thresholds (Tixier et al. 2000), and the survival of predatory mites which arrive in the cropping area can be poor (Tixier et al. 2006). Numerous studies have shown positive effects of semi-natural vegetation on enhancing the density of natural enemies (Asteraki et al. 2004), but authors indicate that the landscape context as well as field margins should be taken into account (Marshall et al. 2006; Winqvist et al. 2012; Ma et al. 2013). Trees and shrubs can not only host a number of phytoseiid species but can also play a key role in the aerial immigration of predatory mites over modest distances (Boller et al. 1988; Jung and Croft 2001; Kazmierczak and Lewandowski 2006; Tixier et al. 2006).

Here, we investigated how the management of field margins affected the colonization and occurrence of beneficial predatory mites in strawberry plantations. The objectives of our on-farm study were: (a) testing the distance of colonization of the strawberry field from the field margins by the predatory mites; (b) assessment of management types favouring high densities of predatory mites; (c) the role of neighbouring woody plant species hosting predatory mites that could disperse into the field. 


\section{Materials and methods}

\section{Study sites and experimental design}

A total of 14 extensive open-field strawberry plantations in central Poland in regions specialized in strawberry production were selected as study sites, where in years 2008-2012 detailed surveys were carried out on both vegetation and mite density. The size of the fields varied from 0.009 to 4.16 ha (Table 1). All farms are located in a flat landscape, characterized by intensive vegetable and fruit production on moderately poor soils. The neighbourhood of the selected farms consists mostly of conventional agricultural fields and rural areas. The sites were planted with the varieties Honoe or Ducat. All plantations were typical extensively managed open field plantations with approximately 30,000 plants per ha and an initial spacing of $25-35 \mathrm{~cm}$ between plants and $1 \mathrm{~m}$ between rows. The plantations were 3-4 years old at the time of the study. Each of the fields was surrounded with well-developed field margin strips but these strips were differently managed. Areas bereft of field margins or where chemical treatment was applied within the last 3 years were excluded from the study (on the basis of questionnaires performed with the owners). The structure of a typical plantation along with its surrounding vegetation is shown in Fig. 1.

\section{Vegetation characteristics}

To test the potential of field margins surrounding the strawberry crops as a source of beneficial predatory mites and test the ability of mites to penetrate into the crop we performed a detailed inventory of the vegetation composition of the fields and their margins. Our preliminary research in strawberry plantations revealed that vegetation consisting mainly of species that host phytoseiids, including plants such as Rubus fruticosus, Sambucus nigra, Rubus idaeus, Rubus caesius, Ribes nigrum, Prunus domestica, Prunus spinosa and Urtica dioica (Wissuwa et al. 2012). We investigated vegetation composition of the strawberry plantations during the vegetation season in 2008. Due to differences in vegetation

Table 1 Location and characteristics of sampled strawberry plantations

\begin{tabular}{lllll}
\hline No. & Area [ha] & Perimeter $[\mathrm{m}]$ & Longitude $(\mathrm{X})$ & Latitude $(\mathrm{Y})$ \\
\hline 1 & 0.042 & 183.2 & $52^{\circ} 33^{\prime} 52.759^{\prime \prime} \mathrm{N}$ & $20^{\circ} 40^{\prime} 44.7557^{\prime \prime} \mathrm{E}$ \\
2 & 4.168 & 831.9 & $52^{\circ} 24^{\prime} 21.986^{\prime \prime} \mathrm{N}$ & $20^{\circ} 18^{\prime} 41.9646^{\prime \prime} \mathrm{E}$ \\
3 & 2.697 & 713.7 & $52^{\circ} 26^{\prime} 14.063^{\prime \prime} \mathrm{N}$ & $20^{\circ} 15^{\prime} 14.905^{\prime \prime} \mathrm{E}$ \\
4 & 0.762 & 405.8 & $51^{\circ} 25^{\prime} 40.948^{\prime \prime} \mathrm{N}$ & $21^{\circ} 53^{\prime} 8.5776^{\prime \prime} \mathrm{E}$ \\
5 & 0.418 & 297.2 & $51^{\circ} 25^{\prime} 44.914^{\prime \prime} \mathrm{N}$ & $21^{\circ} 53^{\prime} 7.5071^{\prime \prime} \mathrm{E}$ \\
6 & 0.727 & 415.2 & $51^{\circ} 26^{\prime} 47.746^{\prime \prime} \mathrm{N}$ & $21^{\circ} 53^{\prime} 1.6844^{\prime \prime} \mathrm{E}$ \\
7 & 0.064 & 235.4 & $51^{\circ} 26^{\prime} 48.312^{\prime \prime} \mathrm{N}$ & $21^{\circ} 53^{\prime} 0.4872^{\prime \prime} \mathrm{E}$ \\
8 & 0.248 & 244.2 & $52^{\circ} 33^{\prime} 8.85^{\prime \prime} \mathrm{N}$ & $20^{\circ} 40^{\prime} 51.0467^{\prime \prime} \mathrm{E}$ \\
9 & 0.046 & 123.4 & $51^{\circ} 26^{\prime} 19.671^{\prime \prime} \mathrm{N}$ & $22^{\circ} 39^{\prime} 15.8821^{\prime \prime} \mathrm{E}$ \\
10 & 0.009 & 45.0 & $51^{\circ} 26^{\prime} 19.544^{\prime \prime} \mathrm{N}$ & $22^{\circ} 39^{\prime} 16.7038^{\prime \prime} \mathrm{E}$ \\
11 & 0.083 & 190.5 & $51^{\circ} 26^{\prime} 3.68^{\prime \prime} \mathrm{N}$ & $22^{\circ} 39^{\prime} 49.6008^{\prime \prime} \mathrm{E}$ \\
12 & 0.759 & 419.7 & $51^{\circ} 23^{\prime} 39.168^{\prime \prime} \mathrm{N}$ & $21^{\circ} 49^{\prime} 53.9508^{\prime \prime} \mathrm{E}$ \\
13 & 1.206 & 444.2 & $51^{\circ} 23^{\prime} 42.186^{\prime \prime} \mathrm{N}$ & $21^{\circ} 50^{\prime} 1.7786^{\prime \prime} \mathrm{E}$ \\
14 & 0.527 & 337.9 & $51^{\circ} 23^{\prime} 39.119^{\prime \prime} \mathrm{N}$ & $21^{\circ} 50^{\prime} 6.2088^{\prime \prime} \mathrm{E}$ \\
\hline
\end{tabular}


a

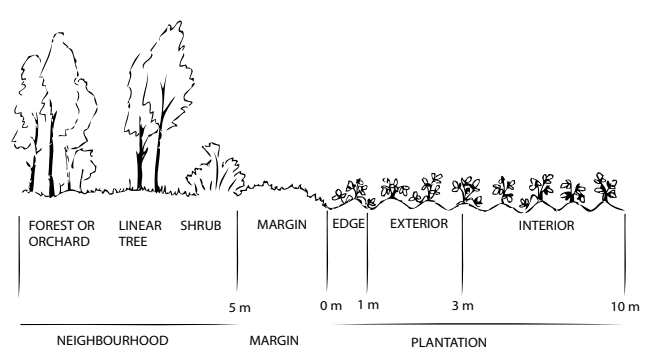

b

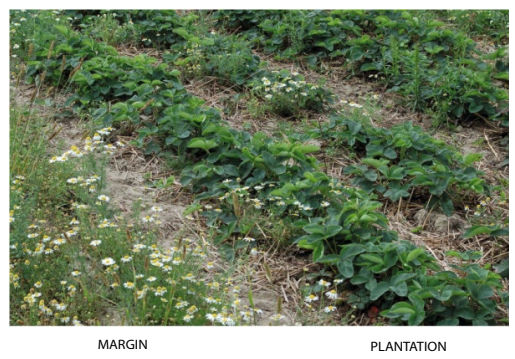

Fig. 1 a Spatial structure of the strawberry plantation and its surroundings: MARGIN, strip of spontaneous natural and semi-natural vegetation adjacent to strawberry field; EDGE, field edge, most exterior part of the plantation, transitional zone between the main crop and the field margin, width of approximately $1 \mathrm{~m}$ (usually restricted to the first row of strawberries); EXTERIOR, crop exterior, $3 \mathrm{~m}$ away from the plantation edge (4-5th row); INTERIOR, crop interior, $10 \mathrm{~m}$ away from the edge (interior part of plantation). b Example of a plot with a field margin and with non-crop vegetation within the plantation

composition (the crops were always accompanied by spontaneous non-crop plant species occurring in the plantations) we distinguished separate zones within the plantation-interior crop (INTERIOR) located in the central part of plantation at least $3 \mathrm{~m}$ inwards from the field edge, exterior crop (EXTERIOR) consisting of strawberry crop from 1 to $3 \mathrm{~m}$ from the edge and field edge (EDGE) (1 m wide strip of strawberry crop directly adjacent to the field margin, the crop area most frequently accompanied by plant species dispersing from the margin), field margin (MARGIN) $0.5-1.5 \mathrm{~m}$ strip of non-crop annual and perennial vegetation surrounding the main crop. Within the distinguished zones, vegetation was recorded, all plant species present were identified and their percentage cover was estimated in $8 \times 2 \mathrm{~m}$ randomly selected plots (Dierschke 1994). The level of change due to anthropogenic pressure in the field margin in sampling plots was assessed on the basis of: plant species cover, number of species, Shannon Diversity Index (SHDI), Simpson Diversity Index (SDI), Dominance Index, share of alien plant species (i.e., non-native species that were introduced by humans, either deliberately or accidentally after year 1500, Mirek at al. 2002, Warren 2007), and share of annual plant species in the plot (BiolFlor; Klotz, and Kühn 2002). Data from each plantation were averaged and standardized. Botanical plant names followed Mirek et al. (2002). The boundaries of each of the strawberry fields along with the field margins were inventoried using a GPS device. Spatial structure (shape) of each strawberry plantation was obtained using a GPS device and transformed into a GIS vector layer (ArcMap 10.2. ESRI).

\section{Field margin management}

On the basis of vegetation composition, we identified different management types of the field margins. An example of a plantation with a visible field margin vegetation is shown in Fig. 1b. We divided the existing margins into the following types:

- stable - well established vegetation consisting of dense perennial vegetation, including woody plants, associated with hedges, fences, ditches, roads;

- mown-strips of predominantly grass, subject to regular intensive cutting, often used as an access road for heavy machinery; not tilled; 
- fallow-strip of vegetation regularly but infrequently tilled, less than once in 3 years, consisting of ruderal vegetation, mostly biennial plants;

- segetal-strip of regularly and frequently tilled non-crop spontaneous vegetation, usually tilled along with the main strawberry crop every 1-2 years consisting mostly of annual plants associated with high disturbance.

\section{Neighbourhood}

The neighbourhood of the plantation beyond the field margins was also taken into account as a factor that might affect the occurrence of mites. Due to the potential aerial dispersal of mites, an inventory of all wooded areas within a distance of $500 \mathrm{~m}$ from the plantation edge was made. Different types of forested areas in the plantation neighbourhood were distinguished:

$\begin{array}{ll}\text { FOREST } & \text { Well established patches of dense deciduous or mixed forest stands } \\ \text { SHRUB } & \text { Groups of shrubs and smaller trees, early to middle succession stage } \\ \text { LINEAR TREE } & \text { Artificial tree plantings most commonly along roads and fences } \\ \text { ORCHARDS } & \begin{array}{l}\text { Areas covered with permanent woody fruit trees, most commonly apple } \\ \text { or cherry orchards. }\end{array}\end{array}$

\section{Mite sampling}

Plant leaves were collected for both predatory mite sampling and to measure the prey density of T. urticae in each of the distinguished plantation zones and the margin (Fig. 1aMARGIN, EDGE, EXTERIOR, INTERIOR). To assess how the different plant species were potentially associated with predatory mites, collecting of invertebrates was performed from the leaves sampled from all distinguished plantation zones in June, July, September and August in 2008 and again in 2009. Samples were collected in field margins from both shrub and herbaceous vegetation leaves, in other zones only from strawberry leaves. Each time 20 leaves were collected from randomly selected individual plants, the species of the plant was also recorded. Sampled material was labelled and placed in separate polyethylene bags and stored in refrigerators. Counting of predatory mites and T. urticae was performed simultaneously within three days of sampling for subsequent species identification under a microscope. All stages of phytoseiid mites found on the leaves were counted and slide mounted for further species identification, the total number of prey was also assessed. For herbivorous mites from each of the plantation parts, several individuals were slide mounted to verify species identification. All adult stages within the investigated plantations were $T$. urticae so juvenile stages can safely be assumed to also belong to this species. To calculate the leaf size, its surface was digitalized and measured using DigiShape software (Cortex. Nova). Mite density was presented as individuals per $\mathrm{m}^{2}$ of the leaf area.

\section{Analysis}

The density of both predatory mites and their prey in separate months was analysed in relation to the characteristics of distinguished vegetation zones. To avoid the effect of external factors, such as climatic conditions data for each month were averaged for years 2008 and 2009 and presented altogether. The data for the predatory mites and their prey T. urticae 
numbers for each year are presented in Appendices 1 and 2. For all variables describing the vegetation structure (i.e., plant species cover, total number of species, Shannon Diversity Index, Simpson Diversity Index, percentage of alien plant species), comparisons between the different zones were done with a non-parametric Kruskal-Wallis test $(\alpha=0.05)$ followed by multiple comparisons of mean ranks between pairs of groups. Multivariate relationships between examined variables were evaluated using principal component analysis (PCA) and results were presented as plots of two components (PC1 and PC2). A Generalized Linear Mixed Model (GLM) with a binomial error distribution and logit link function for the main analysis was applied for evaluation of the effect of factors associated with field margin management, plantation neighbourhood, as well as time of observation (month), which were used as fixed factors in the model. The year of observation was treated as a random variable affecting total phytoseiid density as response variable. In case of management, only two dominant management types were included in the analysis for statistical reasons. The response variables were transformed into dichotomous variables. The analyses were performed in Statistica 10 (StatSoft) and SPSS 24 (IBM) programs.

\section{Results}

Despite the intense agricultural practice within the strawberry plantations, their field margins are characterized by diverse vegetation. While the mean number of vascular plant species in the margin was over 16 per sampled area, there were on average only eight species in the central part of the plantation, consisting of plant species that are well adapted to high disturbance levels, with a high proportion of alien species (Table 2). However, the crop was always accompanied by other herbaceous vegetation, revealing the extensive plantation management and the ability of the examined strawberry plantations to potentially provide pollen sources to generalist phytoseiids, even in the central part of plantation, where common temporarily occurring plants appear, mostly annuals such as Chenopodium album, Galinsogo parviflora, Echinochloa crus-galli, Equisetum arvense, Conyza canadensis. Also, the share of alien plant species increased significantly within the central part of the plantation compared to the margins (Table 2).

Fourteen different phytoseiid species were found in the strawberry plantations and their field margins, the six species occurring in more than $20 \%$ of the samples were Amblyseius andersoni (Chant), Euseius finlandicus (Oudemans), Amblyseius bryophilus (Karg),

Table 2 Differences in vegetation characteristics between different zones of the strawberry plantation

\begin{tabular}{llllll}
\hline Parameter/ zone & Margin & Edge & Exterior & Interior & $\mathrm{p}$ \\
\hline Plant species cover & $102.964 \mathrm{~b} *$ & $80.086 \mathrm{ab}$ & $79.600 \mathrm{ab}$ & $51.607 \mathrm{a}$ & $\mathbf{0 . 0 0 1 1}$ \\
Number of species & $16.357 \mathrm{~b}$ & $12.357 \mathrm{ab}$ & $12.929 \mathrm{ab}$ & $8.643 \mathrm{a}$ & $\mathbf{0 . 0 0 0 7}$ \\
SHDI & 1.411 & 1.416 & 1.370 & 1.055 & 0.20 \\
SDI & 0.601 & 0.632 & 0.632 & 0.513 & 0.38 \\
Alien plant species [\%] & $0.177 \mathrm{a}$ & $0.443 \mathrm{ab}$ & $0.563 \mathrm{ab}$ & $0.697 \mathrm{~b}$ & $\mathbf{0 . 0 0 4 5}$ \\
\hline
\end{tabular}

*Different letters within the same row indicate significant differences between means on the basis of Kruskal-Wallis test and multiple comparisons of mean ranks $(\mathrm{p}<0.05)$

MARGIN field margin, EDGE field edge, EXTERIOR field exterior, INTERIOR field interior, SHDI Shannon-Wiener diversity index, SDI Simpson diversity index, significant differences shown in bold 
Phytoseius echinus (Waistein and Arutunjan), Typhlodromus pyri (Scheuten), Neoseiulus reductus (Wainstein). Together these species represented $93 \%$ of all identified mites (Table 3).

Tetranychus urticae, the main food source for many phytoseiid species, were found in large numbers throughout the strawberry plantations. Highest densities of T. urticae were observed in June in the field margins, with on average 1113.1 individuals per $\mathrm{m}^{2}$ of leaf (Table 4). Because leaf size varied between 10 and $20 \mathrm{~cm}^{2}$, this would result in a maximum density of 2.4 mites per leaf. The number of prey was reduced further into the plantation, but remained above an average of 50 mites per $\mathrm{m}^{2}$ of leaf (Table 4). Densities of spider mites decreased significantly over the course of the years in all zones within the plantation, but remained stable in the margins (Table 4). Despite the presence of this food throughout the plantation, phytoseiid species were only found in high densities in the margins and

Table 3 Mean $( \pm S E)$ number of predatory mites (Phytoseiidae) per $\mathrm{m}^{2}$ leaf area in distinguished plantation zones, significant differences marked in bold

\begin{tabular}{|c|c|c|c|c|c|c|}
\hline & Species & Field margin & Field edge & Field exterior & Field interior & $\mathrm{p}$ \\
\hline \multirow[t]{7}{*}{ June } & A. andersoni & $4.927 \pm 2.595$ & $0.026 \pm 0.026$ & $0.508 \pm 0.459$ & 0 & 0.028 \\
\hline & A. bryophilus & $1.495 \pm 1.495$ & 0 & 0 & 0 & 0.40 \\
\hline & E. finlandicus & $1.874 \pm 0.905 b$ & $0 \mathrm{a}$ & $0 \mathrm{a}$ & $0 \mathrm{a}$ & 0.0089 \\
\hline & N. reductus & $0.947 \pm 0.573$ & 0 & 0 & 0 & 0.053 \\
\hline & P. echinus & $0.829 \pm 0.816$ & 0 & 0 & 0 & 0.39 \\
\hline & T. pyri & $0.297 \pm 0.204$ & 0 & 0 & 0 & 0.11 \\
\hline & TOTAL & $10.616 \pm 3.970 \mathrm{~b}$ & $0.026 \pm 0.026 \mathrm{a}$ & $0.514 \pm 0.459 \mathrm{a}$ & $0 \mathrm{a}$ & 0.0006 \\
\hline \multirow[t]{7}{*}{ July } & A. andersoni & $10.262 \pm 6.375$ & $0.440 \pm 0.440$ & $0.422 \pm 0.422$ & 0 & 0.076 \\
\hline & A. bryophilus & $7.124 \pm 5.956$ & 0 & 0 & 0 & 0.24 \\
\hline & E. finlandicus & $1.852 \pm 0.571 b$ & $0 \mathrm{a}$ & $0.019 \pm 0.019 \mathrm{a}$ & $0 \mathrm{a}$ & $<0.0001$ \\
\hline & N. reductus & $2.146 \pm 1.777$ & 0 & 0 & 0 & 0.24 \\
\hline & P. echinus & $0.802 \pm 0.633$ & 0 & 0 & 0 & 0.20 \\
\hline & T. pyri & $1.401 \pm 1.006$ & 0 & 0 & 0 & 0.13 \\
\hline & TOTAL & $24.464 \pm 9.772 b$ & $0.927 \pm 0.582 \mathrm{a}$ & $0.446 \pm 0.421 \mathrm{a}$ & $0.004 \pm 0.004 \mathrm{a}$ & 0.0014 \\
\hline \multirow[t]{11}{*}{ August } & A. andersoni & $8.904 \pm 2.799$ & $0.109 \pm 0.102$ & $0.103 \pm 0.103$ & 0 & $<0.0001$ \\
\hline & A. bryophilus & $2.051 \pm 1.926$ & $0.056 \pm 0.056$ & 0 & 0 & 0.35 \\
\hline & E. finlandicus & $4.489 \pm 2.128 b$ & $0.015 \pm 0.015 \mathrm{a}$ & $0 \mathrm{a}$ & $0 \mathrm{a}$ & 0.0075 \\
\hline & N. reductus & $1.045 \pm 0.843$ & 0 & 0 & 0 & 0.22 \\
\hline & P. echinus & $6.075 \pm 4.681$ & 0 & 0 & 0 & 0.18 \\
\hline & T. pyri & $5.822 \pm 5.371$ & 0 & 0 & 0 & 0.33 \\
\hline & TOTAL & $29.170 \pm 8.081 b$ & $0.214 \pm 0.113 a$ & $0.103 \pm 0.103 a$ & $0 \mathrm{a}$ & $<0.0001$ \\
\hline & A. andersoni & $4.926 \pm 2.542 b$ & $0.041 \mathrm{a} \pm 0.041$ & $0.037 \pm 0.037 \mathrm{a}$ & $0 \mathrm{a}$ & 0.017 \\
\hline & A. bryophilus & $3.720 \pm 2.658$ & $0.278 \pm 0.206$ & 0 & 0 & 0.15 \\
\hline & E. finlandicus & $2.200 \pm 1.063 b$ & $0 \mathrm{a}$ & $0.019 \pm 0.019 \mathrm{a}$ & $0.016 \pm 0.016 \mathrm{a}$ & 0.0094 \\
\hline & N. reductus & $0.753 \pm 0.726$ & 0 & 0 & 0 & 0.37 \\
\hline \multirow[t]{3}{*}{ September } & P. echinus & $3.466 \pm 2.361$ & 0 & 0 & 0 & 0.10 \\
\hline & T. pyri & $2.825 \pm 2.637$ & 0 & 0 & 0 & 0.34 \\
\hline & TOTAL & $21.147 \pm 4.787 b$ & $0.389 \pm 0.210 \mathrm{a}$ & $0.056 \pm 0.041 \mathrm{a}$ & $0.016 \pm 0.016 \mathrm{a}$ & $<0.0001$ \\
\hline
\end{tabular}

Means wihin a row followed by different letters are significantly different (Kruskal-Wallis test and multiple comparisons of mean ranks: $\mathrm{p}<0.05$ ) 
sometimes in the field exterior. The numbers dropped drastically at the edge of plantations and the predatory mites were seldomly found in the central part of the plantation, thus mite penetration from the field margins into the field was regarded as limited. Only three phytoseiid species were found to have migrated onto crop plants and were found outside the margin. The two most abundant species, A. andersoni and E. finlandicus, frequently inhabited field margins and were found within the plantation in small numbers only, never reaching the central part of plantation. A. bryophilus were sporadically found further from the field edge and E. finlandicus was even observed in the field interior (Table 3). Despite its higher densities, the presence of $A$. andersoni was restricted to the margin and field edge. Though the distribution of predatory mites across the field margins towards the central plantation gradient did not change significantly during the vegetation season (June-September), three phytoseiid species were noted in different field zones. The total number of phytoseiids was significantly higher in the edges throughout the season, despite changes in phytoseiid community composition (Table 3). The remaining dominant phytoseiids, P. echinus, T. pyri, and $N$. reductus, were restricted to the margin. Despite the overall limited dispersal identified in this study, the densities of prey decreased significantly in the whole plantation over the course of growing season.

Apart from the location (zone), the occurrence of phytoseiids in strawberry plantations was also affected by the management of the field margins, as shown in the GLMM analysis (Table 5; Fig. 3), but it was only investigated for the two dominant management types (fallow and segetal). No significant effect was observed for woody plants-combined trees, shrubs, forests and orchards in the neighbourhood (Table 5). The relations of phytoseiids and their neighbourhood are species-specific and vary in time. The results of the PCA analyses in Fig. 2 present relationships between the set of variables which affected the abundance of predatory mites evaluated in subsequent months based on the first and the second principal components (PC1 and PC2). The length of the vectors (Fig. 2) that are parallel to horizontal axis indicate the most important variables, explaining a large part of variability of the total dataset. The two principal components (PC1 and PC2) in all four months explained approximately $40 \%$ of the predatory mite occurrence. The population of the most abundant predatory mite, A. andersoni, was related to the occurrence of spontaneous vegetation in the field margins in June, July (not September) and August (Fig. 2) and showed a negative relation to the presence of forest and trees. The presence of this phytoseiid in August and September was related to the shrubs in the neighbourhood but also to orchards. E. finlandicus was mostly found in areas characterized by higher diversity of plants (number of species), such as fallows in the margins which can also be explained by the fact that

Table 4 Mean $( \pm \mathrm{SE})$ prey abundance (Tetranychus urticae) per $\mathrm{m}^{2}$ leaf area in the distinguished plantation zones, significant differences between months marked in bold

\begin{tabular}{lllll}
\hline & Field margin & Field edge & Field exterior & Field interior \\
\hline June & $1113.1 \pm 781.0$ & $726.7 \pm 243.4 \mathrm{~b}$ & $813.8 \pm 231.3 \mathrm{~b}$ & $994.14 \pm 379.4 \mathrm{~b}$ \\
July & $947.3 \pm 718.9$ & $187.2 \pm 89.5 \mathrm{ab}$ & $241.6 \pm 122.4 \mathrm{ab}$ & $185.6 \pm 73.0 \mathrm{ab}$ \\
August & $261.8 \pm 119.9$ & $135.5 \pm 66.0 \mathrm{a}$ & $227.7 \pm 147.6 \mathrm{a}$ & $163.8 \pm 62.1 \mathrm{a}$ \\
September & $531.5 \pm 406.4$ & $100.0 \pm 56.7 \mathrm{a}$ & $71.1 \pm 34.9 \mathrm{a}$ & $270.6 \pm 143.0 \mathrm{ab}$ \\
$\mathrm{p}$ & 0.088 & $\mathbf{0 . 0 0 1 3}$ & $\mathbf{0 . 0 0 0 6}$ & $\mathbf{0 . 0 2 7}$ \\
\hline
\end{tabular}

Means wihin a column followed by different letters are significantly different (Kruskal-Wallis test and multiple comparisons of mean ranks: $\mathrm{p}<0.05$ ) 
Table 5 Results of GLMM (Generalized Linear Mixed Model), total number of phytoseiids transformed into dichotomous variables as response variable, fixed effects included in the model were factors associated with field margins management—zone (MARGIN—field margin, EDGE—field edge, EXTERIOR—-field exterior, INTERIOR-field interior), management type and total percentage of tree-covered areas in the plantation neighbourhood-forests, shrubs, linear tree stands and orchards altogether, effect of the year was treated as random effect; p-values for significant effects marked in bold

\begin{tabular}{lllc}
\hline Effects & df & F & p-value \\
\hline $\begin{array}{l}\text { Zone (MARGIN, EDGE, EXTERIOR, } \\
\text { INTERIOR) }\end{array}$ & 3 & 37.300 & $<\mathbf{0 . 0 0 1}$ \\
$\begin{array}{l}\text { Management type (stable, lawn, fallow, } \\
\quad \text { segetal) }\end{array}$ & 1 & 13.372 & $<\mathbf{0 . 0 0 1}$ \\
Month & 3 & 2.787 & $\mathbf{0 . 0 4 0}$ \\
Trees total [\%] & 1 & 2.160 & 0.14 \\
\hline
\end{tabular}
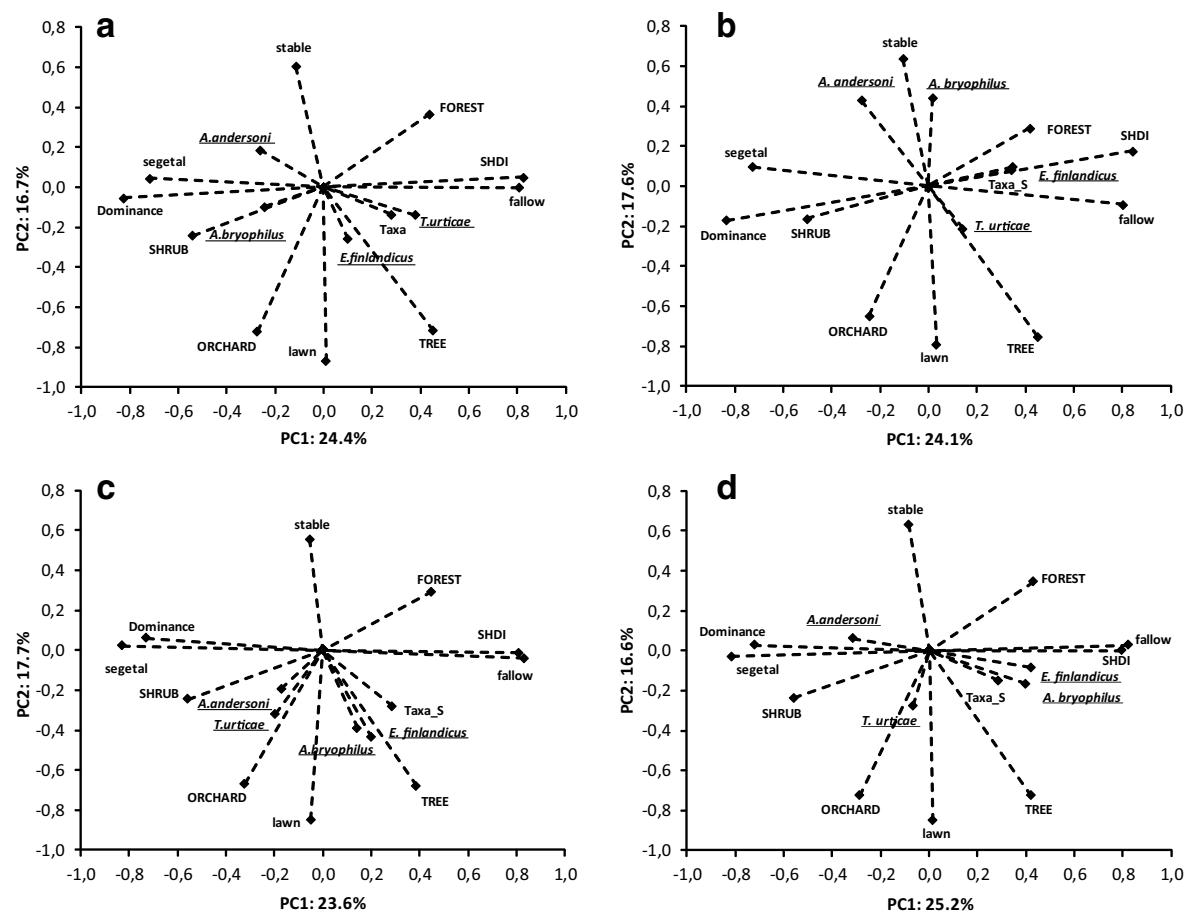

Fig. 2 Principal component analysis (PCA) showing predatory mite preferences for plantation characteristics: field margin vegetation: taxa-plant species richness; Shannon_H—Shannon diversity index, Dominance_D; field margin type-stable, meadow, fallow, segetal; percentage of areas in the surroundings: forests-FOREST, shrubs and smaller trees-SHRUB, orchards - ORCHARD, linear tree plantingsTREE and density of predatory mites: Amblyseius andersoni, Amblyseius bryophilus and Euseius finlandicus in June a, July b, August $\mathbf{c}$ and September $\mathbf{d}$

this species was found only in low numbers outside the fields. Over the entire growing season, the presence of trees was important for this species, as was the presence of forests at the beginning of the season (July). 

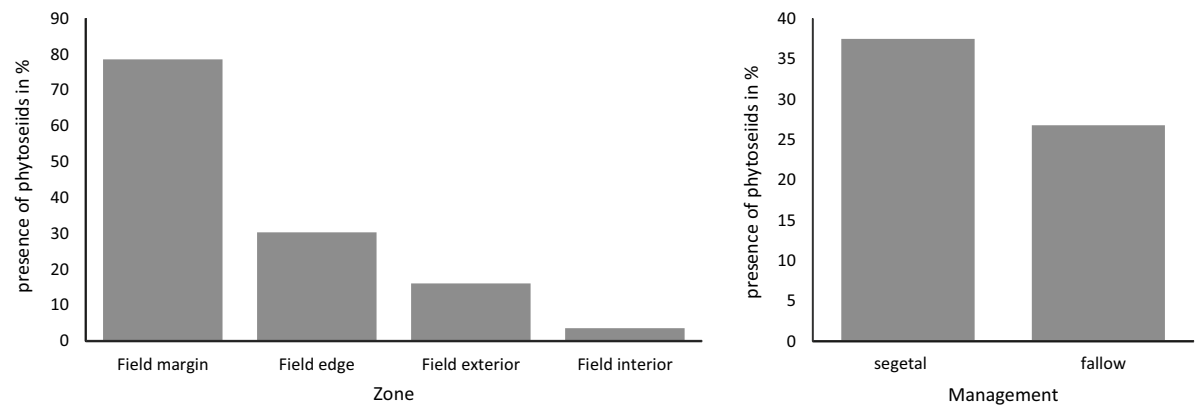

Fig. 3 Percentage of phytoseiids numbers recorded in different plantation zones and under various management types (segetal, fallow), which were the variables significantly affecting phytoseiid abundance according to a GLMM (Table 5)

From June until September, the density of A. bryophilus was related to the occurrence of shrubs in the neighbourhood, but also to the presence meadows and orchard during most of the year (exception September). The occurrence of $E$. finlandicus was most related to the presence of single tree plantings through the majority of the vegetation season. Most frequently, the mites were found on the leaves of woody perennial species such as Sambucus nigra, Prunus spinosa, Rubus fruticosus agg. or Corylus avellana, they were also common on other perennial plants such as Urtica dioica and Lamium album.

\section{Discussion}

Whilst the nature of the field margins and the surrounding landscape could enhance the densities of some species of predatory mites, this study found that the changes in the densities were almost entirely limited to the immediate margins of the field, despite the prey available in the entire field. The management type of the field margins was significantly correlated to the general density of predatory mites in the field margins, spontaneous noncrop vegetation being associated most with the presence of the most common phytoseiid, A. andersoni. There was little evidence of predatory mites dispersing into the interior of the strawberry plantation, but significant reductions in numbers of their prey T. urticae was recorded over the course of the growing season. Whilst conservation biological control is regarded as a potential contributor to IPM (Ramsden et al. 2015), the presence of higher predatory mite densities in margins can offer little control of plant feeding mites if they are retained in the field margins. Rich and diverse vegetation in field margins can act as a source of natural enemies of some crop pests, but the density and diversity of predators in margins per se is no guarantee of successful biological control if the predators do not enter the field. Based on our results, we suggest that the behavioural patterns of the mites must also be considered, particularly in terms of the limited range of their movement patterns.

Conservation biological control includes the modification of the environment to protect and enhance specific natural enemies to reduce the impact of pests (Hajek 2004), and often focuses on targeted habitat management including field margins. Being the most important control agent of herbivorous mites in strawberry crops, the dependence of phytoseiids on rich and diverse vegetation in the field margins has been established for decades (Thomas and Marshall 1999; Denys and Tscharntke 2002; Koh and Holland 2015; Pozzebon and 
Duso 2008). The spontaneous vegetation occurring in field margins acts as a source of food, especially floral resources, to many generalist predators both Phytoseiidae (Duso et al. 2004) as well as other groups such as Coccinellidae or generalist Syrphidae species, which are natural enemies of aphids (Ramsden et al. 2015). The provision of an additional food source can even decrease the mortality rate of predatory mites due to the insecticide applications because they can feed on alternative food resources and recover more quickly (Pozzebon et al. 2014). So-called banker plants can help to sustain higher natural enemy populations, enabling predators to respond more rapidly to pest outbreaks, which was proven for insects (Ramsden et al. 2015). Other plants are important as overwintering habitats for mites and other small arthropods (Romero and Benson 2005). Finding plants whose attributes can enhance biological control is important (Cortesero et al. 2000; van Rijn et al. 2013; van Rijn and Wäckers 2016), yet we found that predatory mite density is linked most to field margin management type (which affected vegetation composition) and the most favourable margins were associated with the presence of spontaneous non-crop vegetation, probably offering also alternative food sources. The significant management factor revealed by the GLMM (Table 5) was most probably linked to management enhancing the densities of the predators only in the margin of the fields, not affecting the interior. We found only two phytoseiid species with changing densities due to management outside the field margins. The densities of their prey inside the plantation was generally low, and perhaps insufficient to provide food for the phytoseeids to allow spread from the margin. The observed decline in mite densities in the plantation may have been inflicted by external factors, as their food, strawberry leaves, was available during that time. This might have also resulted from the predation of phytoseiids but we cannot confirm this as they were not found in the plantation. These results, however, emphasize the importance of fully understanding the role of different species within crop-pest-predator system.

The dependence of phytoseiids on herbaceous non-crop vegetation has been shown in a number of studies (Cruz et al. 2013; Denys and Tscharntke 2002; Mailloux et al. 2010; Tixier et al. 2006), including the important role of shrubs and trees (Tixier et al. 2000), often related to pollen availability (Duso et al. 2004; van Rijn et al. 2013; van Rijn and Wäckers 2016). Conservation plantings of trees have been demonstrated to contribute to a higher density of natural enemies and to positively affect beta diversity of natural enemies up to $5 \mathrm{~km}$ away (Cortesero et al. 2000). It is tempting to generalize such results to other systems and organisms. Though a rich and diverse vegetation of the field margins is reported to favour densities and occurrence of predatory mites here as well as in previous studies (Jaworski 2000), these results may be difficult to extrapolate to other systems. We found no evidence of a link between mite density and the presence of woody plants in the area, the management of the margins significantly influenced the number of phytoseiids, but particularly not in the main area of the crop.

The populations of predatory mites in field margins may be enhanced in a number of ways, and phytoseiids that feed on herbivorous mite species can migrate the short distance between field margins and crops in both directions (Boller et al. 1988; Cruz et al. 2013; Shimoda and Takabayashi 2001; Tixier et al. 2000, 2006). Mites may also arrive from surrounding trees and shrubs by aerial dispersal, and although the phenomenon is poorly investigated, the distance that the mites can potentially disperse increases with the height of the vegetation (Jung and Croft 2001). Whilst mite densities in this study could be enhanced by landscape factors, no relationship was found between the occurrence of any woody plant type in the neighbourhood on mite densities in the crop. The number of plantations with nearby forest was low in this study, and some authors have indicated that aerial distribution by mites can enhance their densities in crops (Shimoda and Takabayashi 
2001). Tixier et al. (2000) showed the role of woody margins as a source of beneficial arthropods, but only over a short distance, and the capability of mites to penetrate into the crop was only moderate. The majority of reported successes with phytoseiids come from either orchards or vineyards, where the beneficial arthropods can find their shelter in undergrowth vegetation (Solva et al. 1997; Jaques et al. 2015). In the case of strawberries, the conditions for survival within the plantation are severe (less than $50 \%$ of ground covered with vegetation), hence the colonization rates are lower, because mites must travel from the field margins. The results of the PCA from this study revealed that each of the phytoseiid species is associated with a different management type, and the indications are that the occurrence and colonization by predatory mites is very species specific. A. andersoni was the only species found occurring on spontaneous plant species inside the plantation. It is a highly generalist predator species, occurring mostly on plants with glabrous leaves (McMurtry et al. 2013) and feeding on a wide range of prey and on fungi (Pozzebon and Duso 2008; McMurtry et al. 2013). A. andersoni is often abundant on lawns and has been connected with spontaneous vegetation and shrubs providing pollen, and can colonize plantations from wild plants adjacent to the crops (Duso 1989; Duso et al. 2004). Yet grass margins did not contribute to high predatory mite species occurrence in this study, while indicating that it is rather associated with ecologically poor habitats characterized by low numbers of species and the presence of non-native plant species. Although some research indicates that orchards could enhance the dispersal of this phytoseiid (Nicòtina and Cioffi 2002), we did not find evidence for this (Table 4). Emphasizing these components within the field might well be of benefit to the within-field densities of $A$. andersoni, and ultimately benefit biological control of pest mite species. E. finlandicus, the second species which was able to spread from the field margin into the plantation in our study, is reported to be able to invade crops from tall trees, and to a lesser extent from shrubs (Tuovinen 1994). Our study indicates a relationship between phytoseiids with trees and also with forests (Fig. 2). The fallows could also be an important field margin type, because they are rich in species and could play a role in dispersal onto the margins from where the species can disperse into the crops.

To be effective, management strategies that enhance the densities of a predator must take the behaviour of the predator species into consideration. The results of this study indicate that, whilst the management of the field margin plays a key role in enhancing the densities of predatory mites, it only does so in the field margins and to some extent in the field edge. The low dispersal of predatory mites into the main part of the field indicates that conservation biological control measures concerning field margins might not be sufficient on their own to enhance the impact of predatory mites within the field interior. For predatory mites to be effective, and potentially also for other predators with limited mobility, conservation biocontrol must also look into changes in plant biodiversity within the field area.

Acknowledgements This work was also improved thanks to the comments and criticisms from the two anonymous reviewers and the editor whom the authors would like to thank. The authors also thank Prof. D. Kropczyńska-Linkiewicz and the possibility to use the facilities for carrying out surveys. The authors are also grateful to Dr Marek Wierzba for help in plant species identification. The manuscript was also improved by the kind input of Dr Graham Begg of The Hutton Institute, Scotland.

Funding This work was partially funded by the Polish Ministry of Sciene and Higher Education (grant no. N31000832/0556).

Open Access This article is distributed under the terms of the Creative Commons Attribution 4.0 International License (http://creativecommons.org/licenses/by/4.0/), which permits unrestricted use, distribution, 
and reproduction in any medium, provided you give appropriate credit to the original author(s) and the source, provide a link to the Creative Commons license, and indicate if changes were made.

\section{References}

Asteraki EJ, Hart BJ, Ings TC, Manley WJ (2004) Factors influencing the plant and invertebrate diversity of arable field margins. Agric Ecosyst Environ 102:219-231. https://doi.org/10.1016/j.agee.2003.07.003

Bale JS, van Lenteren JC, Bigler F (2008) Biological control and sustainable food production. Philos Trans R Soc Lond B Biol Sci 363:761-776. https://doi.org/10.1098/rstb.2007.2182

Barzman M, Bàrberi P, Birch ANE, Boonekamp P, Dachbrodt-Saaydeh S, Graf B, Hommel B, Jensen JE, Kiss J, Kudsk P, Lamichhane JR, Messéan A, Moonen A-C, Ratnadass A, Ricci P, Sarah J-L, Sattin M (2015) Eight principles of integrated pest management. Agron Sustain Dev 35:1199-1215. https://doi. org/10.1007/s13593-015-0327-9

Boller EF, Renuld U, Candolfi MP (1988) Hedges as potential sources of Typhlodromus pyri, the most important predatory mite in vineyard of Northern Switzerland. Entomophaga 33(2):249-255. https:// doi.org/10.1007/BF02372661

Cortesero A, Stapel J, Lewis W (2000) Understanding and manipulating plant attributes to enhance biological control. Biol Control 17:35-49

Cruz WP, Sarmento RA, Teodoro AV, Neto MP, Ignacio M (2013) Driving factors of the communities of phytophagous and predatory mites in a physic nut plantation and spontaneous plants associated. Exp Appl Acarol 60:509-519. https://doi.org/10.1007/s10493-013-9663-0

Denys C, Tscharntke T (2002) Plant-insect communities and predator-prey ratios in field margin strips, adjacent crop fields, and fallows. Oecologia 130:315-324. https://doi.org/10.1007/s004420100796

Dierschke H (1994) Pflanzensoziologie. Grundlagen und Methoden. Ulmer, Stuttgart, pg. 682

Duso C (1989) Role of the predatory mites Amblyseius aberrans (Oud.), Typhlodromus pyri Scheuten and Amblyseius andersoni (Chant) (Acari, Phytoseiidae) in vineyards. I. The effects of single or mixed phytoseiid population releases on spider mite densities (Acari, Tetranychidae). J Appl Entomol 107:474-492

Duso C, Malagnini V, Paganelli A, Aldegheri L, Bottini M, Otto S (2004) Pollen availability and abundance of predatory phytoseiid mites on natural and secondary hedgerows. Biocontrol 49:397-415

Figueiredo AST, Resende JTV, Morales RGF, Gonçalves APS, Da Silva PR (2012) The role of glandular and non-glandular trichomes in the negative interactions between strawberry cultivars and spider mite. Arthropod Plant Interact 7:53-58. https://doi.org/10.1007/s11829-012-9218-z

Hajek AE (2004) Natural enemies: an introduction to biological control. Cambridge University Press, Cambridge

Jaques JA, Aguilar-Fenollosa E, Hurtado-Ruiz MA, Pina T (2015) Food web engineering to enhance biological control of Tetranychus urticae by phytoseiid mites (Tetranychidae: Phytoseiidae) in citrus. In: Carrillo D, de Moraes G, Peña J (ed) Prospects for biological control of plant feeding mites and other harmful organisms. Prog Biol. Control, vol 19. Springer, Cham, pp 251-269. https://doi. org/10.1007/978-3-319-15042-0_10

Jaworski S (2000) Occurrence of phytoseiid mites (Acari: Phytoseiidae) on blackcurrent plantations and in surrounding vegetation in Southern Poland. IOBC WPRS Bull 23:57-62

Jung C, Croft BA (2001) Aerial dispersal of phytoseiid mites (Acari: Phytoseiidae): estimating falling speed and dispersal distance of adult females. Oikos 94:182-190

Kazmierczak B, Lewandowski M (2006) Phytoseiid mites (Acari: Phytoseiidae) inhabiting coniferous trees in natural habitats in Poland. Biol Lett 43(2):315-326

Klotz S, Kühn I (2002) Ökologische Strategietypen. Schriftenreihe für Vegetationskunde 38:197-201

Koh I, Holland JD (2015) Grassland plantings and landscape natural areas both influence insect natural enemies. Agric Ecosyst Environ 199:190-199. https://doi.org/10.1016/j.agee.2014.09.007

Lagerlö J, Wallin H (1993) The abundance of arthropods along two field margins with different types of vegetation composition: an experimental study. Agric Ecosyst Environ 43:141-154

Ma M, Hietala R, Kuussaari M, Helenius J (2013) Impacts of edge density of field patches on plant species richness and community turnover among margin habitats in agricultural landscapes. Ecol Indic 31:25-34. https://doi.org/10.1016/j.ecolind.2012.07.012

Mailloux J, Bellec F, Kreiter S, Tixier MS, Dubois P (2010) Influence of ground cover management on diversity and density of phytoseiid mites (Acari: Phytoseiidae) in Guadeloupean citrus orchards. Exp Appl Acarol 52:275-290. https://doi.org/10.1007/s10493-010-9367-7 
Marshall EJP, Moonen AC (2002) Field margins in northern Europe: their functions and interactions with agriculture. Agric Ecosyst Environ 89:5-21. https://doi.org/10.1016/S0167-8809(01)00315-2

Marshall EJP, West TM, Kleijn D (2006) Impacts of an agri-environment field margin prescription on the flora and fauna of arable farmland in different landscapes. Agric Ecosyst Enviro 113:36-44. https://doi. org/10.1016/j.agee.2005.08.036

McMurtry JA, Moraes GJD, Sourassou NF (2013) Revision of the lifestyles of phytoseiid mites (Acari: Phytoseiidae) and implications for biological control strategies. Syst Appl Acarol 18:297. https://doi. org/10.11158/saa.18.4.1

Mirek Z, Piękoś-Mirkowa H, Zając A, Zając M (2002) Flowering plants and pteridophytes of Poland. A checklist. Biodivers Pol 1:9-442

Nicòtina M, Cioffi E (2002) Dispersion of Amblyseius andersoni (Chant) (Parasitiformes, Phytoseiidae) on grapevines and hazelnut near apples and peaches in the province of Caserta (Southern Italy). In: Bernini F, Nannelli R, Nuzzaci G, de Lillo E (eds) Acarid Phylogeny and Evolution. Adaptations in mites and ticks. Kluwer Academic, Dordrecht, pp 325-329

Niemczyk E (2000) Occurrence and effectiveness of predatory mites (Phytoseiidae) in controlling two-spotted spider mite (Tetranychus urticae Koch) on black currants. IOBC WPRS Bull 23:53-56

Pozzebon A, Duso C (2008) Grape downy mildew plasmopara viticola, an alternative food for generalist predatory mites occurring in vineyards. Biol Control 45:441-449. https://doi.org/10.1016/j.biocontrol .2008 .02 .001

Pozzebon A, Ahmad S, Tirello P, Lorenzon M, Duso C (2014) Does pollen availability mitigate the impact of pesticides on generalist predatory mites? Biol Control 59:585-596

Ramsden MW, Menéndez R, Leather SR, Wäckers F (2015) Optimizing field margins for biocontrol services: The relative role of aphid abundance, annual floral resources, and overwinter habitat in enhancing aphid natural enemies. Agric Ecosyst Environ 199:94-104. https://doi.org/10.1016/j. agee.2014.08.024

Romero GQ, Benson WW (2005) Biotic interactions of mites, plants and leaf domatia. Curr Opin Plant Biol 8:436-440. https://doi.org/10.1016/j.pbi.2005.05.006

Sances FV, Toscano NC, Oatman ER, Lapre LF, Johnson MW, Voth V (1982) Reductions in plant processes by Tetranychus urticae (Acari: Tetranychidae) feeding on strawberry. Environ Entomol 11:733-737

Shimoda T, Takabayashi J (2001) Migration of specialist insect predators to exploit patchily distributed spider mites. Popul Ecol 43:15-21

Solva J, Zoschg M, Hluchy M, Zacharda M (1997) Predatory phytoseiid mites (Acari: Mesostigmata) in vineyards and fruit orchards in Southern Tyrol. Anzeiger für Schädlingskunde, Pflanzenschutz, Umweltschutz 70:17-19. https://doi.org/10.1007/Bf02009611

Thomas C, Marshall E (1999) Arthropod abundance and diversity in differently vegetated margins of arable fields. Agric Ecosyst Environ 72:131-144

Tirello P, Pozzebon A, Cassanelli S, Van Leeuwen T, Duso C (2012) Resistance to acaricides in Italian strains of Tetranychus urticae: toxicological and enzymatic assays. Exp Appl Acarol 57:53-64. https:// doi.org/10.1007/s10493-012-9536-y

Tixier MS, Kreiter S, Auger P (2000) Colonization of vineyards by phytoseiid mites: their dispersal patterns in the plot and their fate. Exp Appl Acarol 24:191-211

Tixier MS, Kreiter S, Cheval B, Guichou S, Auger P, Bonafos R (2006) Immigration of phytoseiid mites from surrounding uncultivated areas into a newly planted vineyard. Exp Appl Acarol 39:227-242. https://doi.org/10.1007/s10493-006-9010-9

Tuovinen T (1994) Influence of surrounding trees and bushes on the phytoseiid mite fauna on apple orchard trees in Finland. Agr Ecosyst Environ 50:39-47

van Rijn PC, Wäckers FL (2016) Nectar accessibility determines fitness, flower choice and abundance of hoverflies that provide natural pest control. J Appl Ecol 53:925-933. https://doi. org/10.1111/1365-2664.12605

van Rijn PC, Kooijman J, Wäckers FL (2013) The contribution of floral resources and honeydew to the performance of predatory hoverflies (Diptera: Syrphidae). Biol Control 67:32-38

Warren CR (2007) Perspectives on the 'alien' versus 'native' species debate: a critique of concepts, language and practice. Prog Hum Geogr 31:427

Winqvist C, Ahnstrom J, Bengtsson J (2012) Effects of organic farming on biodiversity and ecosystem services: Taking landscape complexity into account. Ann N Y Acad Sci 1249:191-203. https://doi.org/10 $.1111 / \mathrm{j} .1749-6632.2011 .06413 . x$

Wissuwa J, Salamon JA, Frank T (2012) Effects of habitat age and plant species on predatory mites (Acari: Mesostigmata) in grassy arable fallows in Eastern Austria. Soil Biol Biochem 50:96-107. https://doi. org/10.1016/j.soilbio.2012.02.025 
Publisher's Note Springer Nature remains neutral with regard to jurisdictional claims in published maps and institutional affiliations.

\section{Affiliations}

\section{Sikorska ${ }^{1,2}$ (1) J. Garnis ${ }^{3}$ - Z. T. Dąbrowski ${ }^{3}$ P. Sikorski ${ }^{4}$ D. Gozdowski ${ }^{5}$.} R. J. Hopkins ${ }^{6}$

1 Department of Environmental Improvement, Faculty of Civil and Environmental Engineering, Warsaw University of Life Sciences, SGGW, Nowoursynowska 159 Str., 02-776 Warsaw, Poland

2 European Regional Centre for Ecohydrology of the Polish Academy of Sciences, Tylna 3 Str., 90-364 Łódź, Poland

3 Department of Applied Entomology, Faculty of Horticulture, Biotechnology and Landscape Architecture, Warsaw University of Life Sciences, SGGW, Nowoursynowska 159 Str., 02-776 Warsaw, Poland

4 Department of Environmental Protection, Faculty of Horticulture, Biotechnology and Landscape Architecture, Warsaw University of Life Sciences, SGGW, Nowoursynowska 159 Str., 02-776 Warsaw, Poland

5 Department of Experimental Design and Bioinformatics, Faculty of Agriculture and Biology, Warsaw University of Life Sciences, SGGW, Nowoursynowska 159 Str., 02-776 Warsaw, Poland

6 Natural Resources Institute, University of Greenwich, Central Avenue, Chatham Maritime, Kent ME4 4TB, UK 